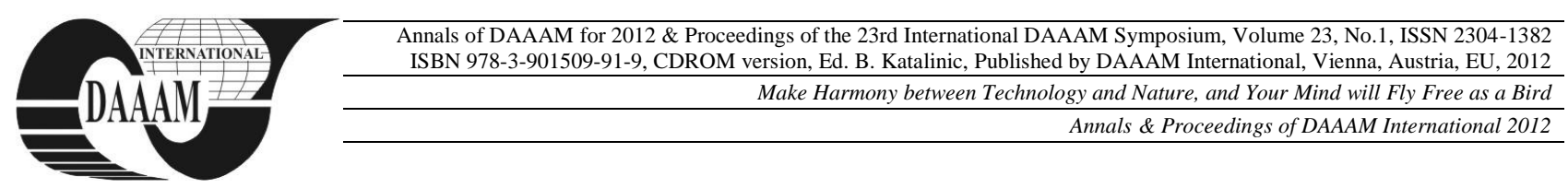

\title{
ROMANIAN NATIONAL ACTION PLAN FOR ENVIRONMENTAL PROTECTION - NAPEP
}

\author{
BUZOIANU, D[aniela] - A[ngela] \& COLOJA, M[ihai] P[ascu]
}

\begin{abstract}
After 1990, in Romania, environmental policy has become a general policy, recognizing its importance for the harmonious development of society. With the main objective to strengthen administrative structures as basic element for building a robust management and contributing to sustainable development, the Romanian government activity in this area (according to the Government Program2009-2012, Chapter 18)[5] will focus on the following priorities:(a) Integration of environmental policy in developing and implementing sectorial and regional policies; (b) Assess the current state of the environment and the foundation of a long-term development strategies in environment, renewable and non-renewable resources; (c) Strengthening institutional capacity in environmental law; (d) Improvement of environmental quality in urban and rural comments; (e) Extending the national network of protected areas and nature reserves, coastal rehabilitation Romanian seaside, environmental and economic scaling of the Danube Delta; (f) Strengthening cross-border and international partnership with similar institutions in other countries for monitoring progress in implementation of the international agreements; $(g)$ Developing strategies to protect citizens against natural disasters, environmental accidents and exposure to environmental risk areas; NAPEP analysis aims to provide a clear picture of investments that are made in Romania for environmental protection
\end{abstract}

Keywords: policies, strategy, plan, environment, protection

\section{INTRODUCTION}

Overall objective is to improve the environmental quality of life in Romania by providing a clean environment which improves the living standards of the population, improve the environment, conservation and improvement of the natural heritage that Romania benefits.

Objectives and actions to protect and improve the environment will follow the principles and strategic elements (contained in the Government Emergency Ordinance no. 195/2005 on environmental protection, approved with amendments and completions by Law no. 265/2006, amended and supplemented ) as follows:

- The principle of integrating environmental requirements into other sectorial policies;

- The precaution principle in decision making;

- Preventive action;

- The principle of retention of pollutants at source;

- The "polluter pays" principle;

- The principle of conservation of biodiversity and ecosystems specific to the natural biogeography;

- Sustainable use of natural resources;
- Public information and participation in decision making and access to justice in environmental matters;

- Development of international cooperation for environmental protection.

\section{Environmental strategic objectives are:}

- Preserving, protecting and improving the environment;

- Protection of human health;

- Sustainable use of natural resources.

General priority objectives of environmental policy are:

- Strengthening the institutional framework for environmental protection harmonized with the European Union and providing material, financial and human resources at central, regional and local levels;

- Ensuring the carrying out environmental investments as arising from the implementation plans and financial plans for implementing the "acquis comunitaire";

- Increased capacity to attract and use of structural funds;

- Increasing the number of jobs in the national economy and reduce unemployment by exploiting the opportunities offered by the administration and implementation of environmental infrastructure;

- Encouraging the development of education and training at all levels, as well as research in the field of environ-mental protection;

- Protection against the effects of natural disasters and accidental pollution, enhancing prevention, control and intervention by creating an improved system of integrated monitoring of the environment and an efficient information system corresponding to UE requirements;

- Introduction of environmental management systems, construction and accreditation of modern environmental laboratories;

- Promoting capacity building instrument, economic elements in environmental protection, cost-benefit analysis for introducing environmental costs in production costs, opportunities offered by the Environ mental Fund;

- Promote use of renewable energy sources and new means of production and consumption, environmental friendly;

- Sustainable use of natural resources, promoting the use of waste as secondary raw materials in order to 
protect natural resources, promote sustainable agriculture and rural development, paying particular attention to endangered flora and those with high economic value;

- Increased attention to environmental relationship, health, environment, transport, agriculture and environment;

- Promote international cooperation overall, regional and bilateral environmental and getting actively involved in the implementation of international environmental conventions.

\section{Priority measures in environmental policy:}

- Sustainable water management and development of water resources, water satisfaction necessary social and economic activities, flood protection, providing meteorological and hydrological monitoring, improving the legal framework, methodologies and regulations of water management, meteorology and hydrology for achieving sustainable management in national and international context and harmonization with UE directives requirements;

- Improving air quality in order to prevent, avoid or reduce harmful effects on human health and the environment as a whole, reducing greenhouse gas emissions, development of national air quality monitoring;

- Environmental impact assessment;

- Industrial pollution control and risk management;

- Waste management by developing integrated management systems;

- Proper management of hazardous chemicals and substances that degrade the ozone layer;

- Protection and biodiversity conservation, ecological restoration.

As a consequence of the strategic objectives mentioned above, in connection with the "acquis" fields, resulting objectives and targets on key environmental areas.

National Action Plan for Environmental Protection is a tool for implementing environmental policies and strategies, which promotes support in achieving its major projects with significant impact on the environment, the application and enforcement of existing legislation [3].

Developing and updating the National Action Plan for Environmental Protection is a complex process, which aims to implement concrete actions and projects, with the ultimate goal to gradually improve environmental quality in Romania. This is done in line with strategic objectives, priority measures and actions at national level coming from analyzes of changes and trends in environmental protection.

This document is intended to provide a full picture of what means, environmental investments that are made at any time in Romania. It is only for regional or national scale projects, or projects that have a significant impact on the size of the problem to which it relates. All other local projects are included in the databases of local environmental action plans, developed at the county level.

National Action Plan for Environmental Protection is the main document to which reference should be made, when we discuss about investments in environmental protection, no matter the perspective we are looking from. Strategic environmental planning involves on the one hand, institutions, public authorities and economic operators, which propose environmental projects, on the other hand those who finance these projects.[1] The main sources of funding are: State budget, local budgets, Environment Fund, European funds, other domestic and international financing sources.[5]

Romania's economic development, increasing human pressure on urban areas and modifying the approach to environmental issues by transposing EU environmental legislation into national law, requires regular updating of the National Action Plan for Environmental Protection. To coordinate the integration of environmental protection in sectorial policies and strategies at national level, was necessary approval by the Interministerial Committee NAPEP, which means, turning it into a programmatic document of the Romanian Government, which is a guarantee to support the promotion and implementation of the plan.

Objectives and targets to ensure soil quality. [4] General objectives:

- Reduction and prevention of pollution and soil degradation;

- Improving soil quality and sustainable use of soil resources.

Specific objectives:

- Identification, investigation and restoration / remediation of contaminated sites;

- Reducing soil pollution caused by agro-industrial activities and remediation of areas affected by accidental pollution;

- Greening areas affected by poorly designed landfills;

- Reducing pollution affected soil infiltration wastewater;

- Reducing soil pollution due to dust settled, acid deposition and heavy metals etc.

- Reducing soil erosion;

- Sandy soil stabilization;

- Reduction in area affected by landslides;

- Rehabilitation of land degraded by human activities;

- Reducing the negative impact caused by the flooding phenomenon-time limits and ponds;

- Prevention of soil degradation through application of best agricultural practices;

- Preserving the ecological functions of soil;

- Improving soil quality in order to increase production capacity;

- Develop a system for monitoring soil quality.

\section{ROMANIAN NATIONAL PLAN FOR ENVIRONMENTAL PROTECTION (NAPEP), AS A TOOL FOR IMPLEMENTING ENVIRONMENTAL POLICIES AND STRTEGIES}

The regular update of NAPEP is coordinated by the National Agency for Environmental Protection and Sustainable Development Directorate, and means reevaluation of national objectives in environmental protection, in line with changes in the state of the environment and specific legislation [3]. 
Optimal conditions for carrying updating process tools were necessary, to establish the framework for coordination and collaboration between components of the organizational structure of the National Action Plan for Environmental Protection. The Minister of Environment and Sustainable Development nr.1170 / 19.07.2007 approved organizational structure of the NAPEP, confirmed by the Interministerial Committee Decision No. 1 / 7.11.2008.

Since most pollution problems are complex and are often generated by several economic sectors, was necessary a cross-sectorial approach to obtain the final optimal solution. Representatives of all key institutions were included, their involvement, from the initial stage, a key point to facilitate the implementation of projects included in the NAPEP.In the working groups identified priority objectives and key environmental areas were developed selection criteria and prioritization of project proposals submitted by traders, institutions, local authorities, non govern-mental organizations to be included in NAPEP.

Distribution of number of projects with significant environmental impacts, admitted NAPEP for 2008-2009 is illustrated in Tab. 1-3 and Figure 1-3presented below.

The portfolio of projects of NAPEP 2008 was 357 included a number of proposals whose position at the end of 2009 is as follows (Tab.3.3.)

- 30 realized projects;

- 105 projects in progress;

- 207 unrealized proposals;

- 9 proposals cancelled.

For the remaining 6 proposals for projects from region 8 (Bucharest), were not submitted information on the status of their implementation.

\begin{tabular}{|c|c|c|c|c|}
\hline Area & $\begin{array}{c}\text { No.1,NE } \\
\text { st region }\end{array}$ & $\begin{array}{c}\text { No.2,SEst } \\
\text { region }\end{array}$ & $\begin{array}{c}\text { No.3,South } \\
\text { region }\end{array}$ & $\begin{array}{c}\text { No.4,SWest } \\
\text { region }\end{array}$ \\
\hline $\begin{array}{c}\text { Pollution } \\
\text { control,air } \\
\text { protection and } \\
\text { climat changes }\end{array}$ & 3 & 1 & 12 & 1 \\
\hline Water & 19 & 10 & 42 & 17 \\
\hline $\begin{array}{c}\text { Scrap and } \\
\text { dangerous } \\
\text { chemicals }\end{array}$ & 9 & 0 & 3 & 4 \\
\hline $\begin{array}{c}\text { Nature } \\
\text { protection, } \\
\text { biodiversity } \\
\text { and forests }\end{array}$ & 2 & 14 & 8 & 4 \\
\hline $\begin{array}{c}\text { City and } \\
\text { village } \\
\text { development } \\
\text { and protection } \\
\text { against noise }\end{array}$ & 3 & 9 & 16 & 2 \\
\hline $\begin{array}{c}\text { Soil quality } \\
\text { and degraded } \\
\text { areas }\end{array}$ & 3 & 3 & 1 & 1 \\
\hline $\begin{array}{c}\text { Enviromental } \\
\text { education }\end{array}$ & 4 & 6 & 3 & 2 \\
\hline \begin{tabular}{c} 
Total \\
\hline
\end{tabular} & 43 & 43 & 85 & 31 \\
\hline
\end{tabular}

Tab.1. The selected projects distribution by region and environmental domains in 2008 [2]

A total of 9 projects were canceled for various reasons: either they closed the objectives for which proposals were made or were included in other projects of greater magnitude. From Tab.1 we can see that Region
3, South- Muntenia has most proposals included in the NAPEP portfolio (85proposals), mostly completed or in progress (4 completed projects, 38 in progress).

Note: The total does not include project proposals directed to environmental action plans at county and regional.

We can observe from the data from Tab.2, that the share of unrealized projects $(58.0 \%)$ exceeds the cumulative share of done projects and those under construction $(29.4 \%)$.

\begin{tabular}{|l|c|c|c|c|c|}
\hline Region & $\begin{array}{l}\text { Project } \\
\text { proposals } \\
\text { NAPEP } \\
\text { included }\end{array}$ & $\begin{array}{l}\text { Realised } \\
\text { projects }\end{array}$ & $\begin{array}{l}\text { In } \\
\text { progress } \\
\text { projects }\end{array}$ & $\begin{array}{l}\text { Not } \\
\text { started }\end{array}$ & $\begin{array}{l}\text { Cancelled } \\
\text { projects }\end{array}$ \\
\hline North-East & 43 & 7 & 18 & 16 & 3 \\
\hline South-East & 43 & 6 & 3 & 34 & 0 \\
\hline South & 85 & 4 & 38 & 39 & 4 \\
\hline $\begin{array}{l}\text { South- } \\
\text { West }\end{array}$ & 31 & 2 & 8 & 21 & 0 \\
\hline West & 56 & 5 & 9 & 42 & 0 \\
\hline $\begin{array}{l}\text { North- } \\
\text { West }\end{array}$ & 42 & 5 & 7 & 30 & 0 \\
\hline Center & 39 & 0 & 22 & 14 & 3 \\
\hline Bucharest & 18 & 1 & 0 & 11 & 6 \\
\hline Total & 357 & 30 & 105 & 207 & 15 \\
\hline
\end{tabular}

Tab.2. NAPEP projects implementation stage by regions in 2009 [2]

\begin{tabular}{|c|c|c|c|c|c|}
\hline Area & $\begin{array}{c}\text { Project } \\
\text { proposals } \\
\text { NAPEP } \\
\text { included }\end{array}$ & $\begin{array}{l}\text { Realised } \\
\text { projects }\end{array}$ & $\begin{array}{c}\text { In } \\
\text { progress } \\
\text { projects }\end{array}$ & $\begin{array}{l}\text { Not } \\
\text { started }\end{array}$ & $\begin{array}{c}\text { Cancelled } \\
\text { projects }\end{array}$ \\
\hline $\begin{array}{l}\text { Pollution } \\
\text { control,air } \\
\text { protection } \\
\text { and climat } \\
\text { changes }\end{array}$ & 39 & 7 & 7 & 24 & 1 \\
\hline Water & 163 & 10 & 61 & 90 & 2 \\
\hline $\begin{array}{l}\text { Scrap and } \\
\text { dangerous } \\
\text { chemicals }\end{array}$ & 23 & 3 & 7 & 13 & 2 \\
\hline $\begin{array}{c}\text { Nature } \\
\text { protection, } \\
\text { biodiversity } \\
\text { and forests }\end{array}$ & 51 & 2 & 8 & 36 & 5 \\
\hline $\begin{array}{c}\text { City and } \\
\text { village } \\
\text { developmen } \\
t \text { and } \\
\text { protection } \\
\text { against } \\
\text { noise } \\
\end{array}$ & 38 & 6 & 15 & 17 & 0 \\
\hline $\begin{array}{l}\text { Soil quality } \\
\text { and } \\
\text { degraded } \\
\text { areas } \\
\end{array}$ & 13 & 1 & 2 & 10 & 0 \\
\hline $\begin{array}{l}\text { Enviroment } \\
\text { al education }\end{array}$ & 28 & 1 & 5 & 17 & 5 \\
\hline Total & 337 & 30 & 105 & 207 & 15 \\
\hline
\end{tabular}

Tab.3. NAPEP projects distribution in stages of implementation and environmental fields [2]

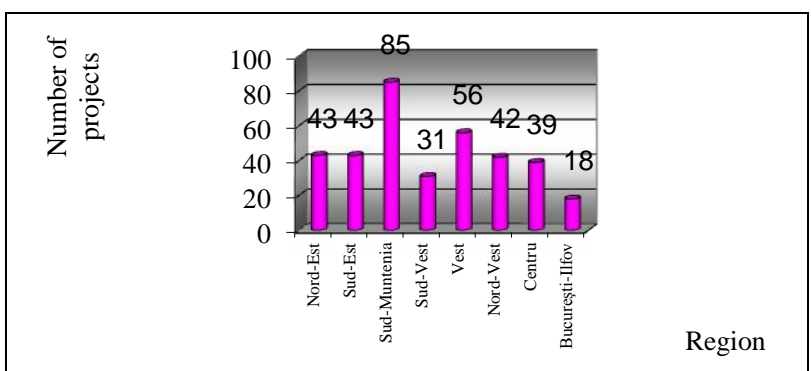

Fig. 1.The selected projects distribution by region in 2008 
Analyzing each situation were identified main causes of the large number of unrealized projects:

- Lack or insufficient financial resources;

- Lack of local support;

- Existence of complicated procedures for accessing funds;

- Lack of information at the county level regarding European funds.

Compared with the large number of proposals included in NAPEP, the number of projects currently being conducted and the achievement is much smaller; there are situations in which these projects represent a small percentage from the initial number of projects

\section{NAPEP PROJECT PROGRESS STATUS RELATED TO ENVIRONMENTAL AREAS}

Analyze of project progress in relation to the areas of environment in which are included, shows that most of them are in water domain $(33.3 \%)$ and the fewest projects were conducted in degraded soil quality and ecological education areas, each having one project completed (3.3\% -fig.2.).

On projects in progress (Tab. 3.), most of them reached the water problems (61projects), followed by the city and village development and protection against noise (15 projects). Most projects were canceled in nature conservation, biodiversity and forests $(7.8 \%$ of projects launched in this area).

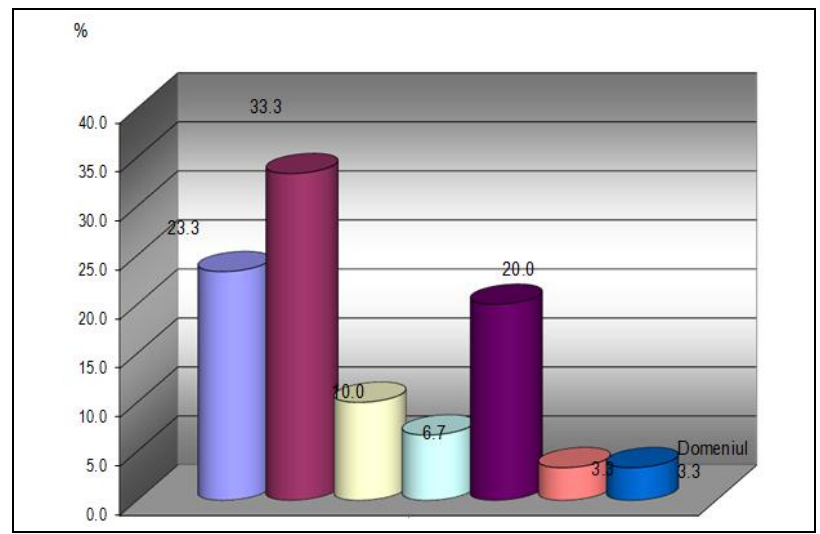

Fig.2 NAPEP Project distribution at national level

Looking at Figure 3, we can see percentage distribution of NAPEP projects, unrealized undergoing the achievement, on average each domain separately. The field planning, rural development and noise protection is most balanced, given that the share of projects completed and in progress is close to the weight of unrealized projects, exceeding $10.6 \%$.

To increase the number of projects implemented and improved financing conditions, have been submitted by users, local authorities and environmental agencies, the following suggestions for improvement:

- Simplification of funding guidelines and procedure for obtaining funds;

- Reducing the period of evaluation of projects,

facilities granted by the Romanian state;
- Reducing bureaucracy and the time necessary settlement of eligible expenses;

- Training programs for representatives of local authorities in accessing funds;

- Initiation of a national strategy to stimulate the associative spirit of local communities;

- Intensifying awareness amongst businesses about environmental compliance.

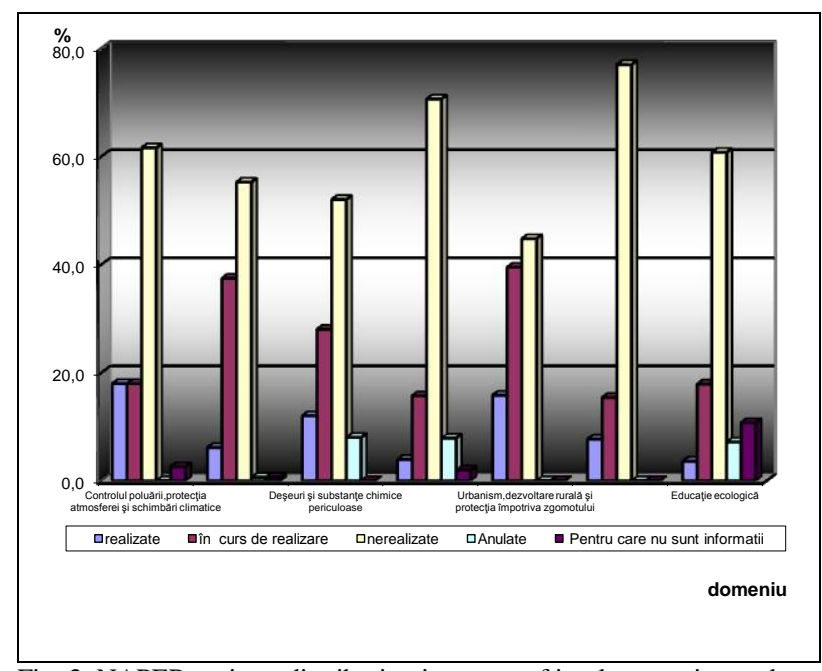

Fig. 3 .NAPEP projects distribution in stages of implementation and environmental fields (\%)in $2008-2009$

\section{CONCLUSION}

Objectives underlying environmental strategy or economic and social development policies in Romania (according to report on the progress of implementation of projects in the National Action Plan for Environmental Protection issued by the Ministry of Environment and Forests and the National Agency for Protection environment) are [5], [3]:

Horizon 2013 - Incorporating the principles and practices of sustainable development into all policies and programs of Romania as a member state of the European Union;

2020 - Reaching the current average level of EU countries, the main indicators of sustainable development;

Horizon 2030 - get significantly close to the average in that year of European Union member countries in terms of sustainable development indicators.

\section{REFERENCES}

[1] Rojanschi,V.;Bran,F.;Diaconu,S.;Grigore,F;(2003),Abordari economice in Protectia Mediului (Economic assumption in Environment protection) Available from:http:// www.bibliotecadigitala.ase.ro Accessed: 2011-11-16

[2] http://www.insse.ro,(2010).The National Statistics Institute, Statistics Year Book, Accessed on: 2012-08-13

[3] http://www.anpm.ro,(2010).The National Environment Protection Agency, Accessed on: 2012-05-18

[4] *** Soil Status in Romania, Romanian Environment Ministery report, 2003-2007

[5] http://www.gov.ro,(2011). Romanian Government Official Site, Accesed on 2012-04-16 